\title{
Lokale en regionale democratie ten tijde van corona
}

\section{Een historisch overzicht met zes perioden}

Carmen Dymanus, Roos Hofstra, Ank Michels \& Albert Meijer ${ }^{*}$

Introductie: beschrijvende ordening van een hectisch jaar

De bestrijding van de coronapandemie beheerste de politiek-bestuurlijke agenda in 2020 en heeft op allerlei manieren een directe impact op het functioneren van het binnenlands bestuur. Niet alleen waren er ingrijpende maatregelen nodig om het coronavirus in te dammen, maar die maatregelen veranderden ook voortdurend, afhankelijk van de ernst van de situatie van het virus. Die steeds veranderende maatregelen hadden niet alleen direct invloed op de persoonlijke levens van mensen en het functioneren van sectoren zoals horeca en sport, maar ook op de lokale democratie. Doordat persoonlijk contact en samenkomsten in grotere groepen op grond van crisismaatregelen niet mogelijk waren, moesten steeds nieuwe manieren worden gezocht om democratische processen vorm te geven binnen de geldende beperkingen.

In de afgelopen periode hebben we een groot reactie- en improvisatievermogen van gemeenten, provincies en waterschappen gezien. De maatregelen om corona te bestrijden bepaalden de ruimte en de opties voor lokaal en regionaal bestuur om democratische besluitvorming en vergaderingen van volksvertegenwoordigingen te organiseren. Daarnaast hadden de maatregelen invloed op de wijze waarop participatietrajecten met burgers vorm kunnen krijgen. Het doel van deze beschrijvende bijdrage is om een overzicht te bieden van de verschillende perioden die er kunnen worden onderscheiden om zo precies aan te geven hoe de landelijke maatregelen van invloed zijn op het functioneren van de democratie op lokaal en regionaal niveau.

In het vervolg van dit artikel onderscheiden we op basis van de dan geldende landelijke maatregelen voor corona zes perioden in het tijdvak van maart 2020 tot en met januari 2021. Voor iedere periode geven we een overzicht van de belangrijkste landelijke maatregelen om de verspreiding van corona te beteugelen en van de belangrijkste ontwikkelingen in het functioneren van het democratisch bestuur. Daarbij besteden we met name aandacht aan de mogelijkheden om

* Carmen Dymanus BSc is junior onderzoeker bij het departement Bestuurs- en Organisatiewetenschap aan de Universiteit Utrecht. Roos Hofstra BSc is junior onderzoeker bij het departement Bestuurs- en Organisatiewetenschap aan de Universiteit Utrecht. Dr. Ank Michels is universitair hoofddocent bij het departement Bestuurs- en Organisatiewetenschap aan de Universiteit Utrecht. Prof. dr. Albert Meijer is hoogleraar publiek management bij het departement Bestuurs- en Organisatiewetenschap aan de Universiteit Utrecht. 
democratische besluiten te nemen in de volksvertegenwoordigende organen, om vergaderingen te laten plaatsvinden en om burgerparticipatie te organiseren, en we noemen praktijken in specifieke gemeenten, provincies en waterschappen om de nieuwe democratische praktijken te illustreren Deze zes perioden laten zo goed de dynamiek in de context van het lokaal en regionaal bestuur ten tijde van corona zien en hoe deze dynamiek de vormgeving van democratische processen beïnvloedt. ${ }^{1}$

\section{Periode 1: Begin van de crisis (9 maart tot 23 maart)}

In deze eerste periode in maart 2020 overvalt de coronacrisis Nederland. Er wordt door de regering in snel tempo een aantal eerst weinig ingrijpende maar gaandeweg steeds drastischere maatregelen genomen om het coronavirus het hoofd te bieden. Ook worden er maatregelen genomen om duidelijkheid te bieden over de implicaties van de coronabestrijding voor gemeenten, provincies, en waterschappen.

\section{Landelijke maatregelen}

Op 9 maart lijkt corona nog redelijk onschuldig en komt het kabinet slechts met een aantal dringende adviezen op het gebied van persoonlijke hygiëne. Het advies aan iedereen is om regelmatig de handen te wassen, in de elleboog te niezen en te hoesten en geen handen meer te schudden. Kort daarna - op 12 maart - worden echter ingrijpendere nieuwe landelijke overheidsmaatregelen afgekondigd. Iedereen in Nederland wordt opgeroepen om thuis te blijven bij klachten als neusverkoudheid, hoesten, keelpijn of koorts. Ook is het verzoek om sociaal contact te mijden en zo veel mogelijk thuis te werken. En verder worden bijeenkomsten met meer dan honderd personen afgelast. Dat geldt ook voor publieke locaties als musea, concertzalen, theaters, sportclubs en sportwedstrijden. De maatregelen volgen elkaar daarna in snel tempo op en hebben grote gevolgen voor de economie en voor sociale contacten tussen mensen. Op 15 maart dienen alle eet- en drinkgelegenheden (behalve die in hotels), sport- en fitnessclubs, sauna's, seksclubs en coffeeshops vanaf 18.00 uur hun deuren te sluiten. Ook het onderwijs blijft in deze periode niet gespaard. Op 16 maart worden alle kinderdagverblijven, basis- en middelbare scholen en scholen voor middelbaar beroepsonderwijs en hoger onderwijs gesloten.

\section{Lokale en regionale democratie}

Naar aanleiding van bovenstaande algemene maatregelen brengt het ministerie van Binnenlandse Zaken en Koninkrijksrelaties (BZK) op 19 maart een richtlijn uit om de betekenis van deze maatregelen te duiden voor het openbaar bestuur. In de richtlijn wordt opgeroepen tot grote terughoudendheid bij gemeenteraden en provinciale staten bij het beleggen van vergaderingen. Het advies is om vergaderingen die niet strikt noodzakelijk zijn uit te stellen, maar BZK laat een uiteindelijk besluit over aan gemeenten. Ook staat in de richtlijn dat zonder fysieke raadsvergadering er in principe geen raadsbesluiten kunnen worden genomen en 
wordt vermeld dat geen publiek meer aanwezig mag zijn bij beraadslagingen. Sommige gemeenten kiezen deze periode voor het 'Amersfoortse model', genoemd naar hoe in Amersfoort snel na het uitbreken van de crisis de raadsvergaderingen worden gevoerd. Dit model houdt in dat een zo klein mogelijke meerderheid van de raadsleden, dus de helft plus één, naar het gemeentehuis komt, waar alleen gestemd wordt, omdat de wet tot dan toe fysieke aanwezigheid verplichtte (www.ad.nl). De debatten kunnen eventueel wel met een videoverbinding worden gevoerd. Veel bewonersbijeenkomsten worden tot nader order geannuleerd.

\section{Periode 2: Intelligente lockdown (23 maart tot 9 april)}

In de tweede periode is de 'intelligente lockdown' de meest ingrijpende maatregel in de bestrijding van corona. Nu komt het dagelijks leven bijna geheel tot stilstand. De maatregelen leiden ertoe dat ook voor democratische processen geen ruimte meer is doordat de strenge bepaling vrijwel elke vorm van sociaal contact verbiedt.

\section{Landelijke maatregelen}

Op 23 maart kondigt het kabinet de 'intelligente lockdown' af. Nederland kiest niet voor een even strenge lockdown als Frankrijk en Spanje, maar toch zijn de maatregelen zeer ingrijpend. Het doel van de intelligente lockdown is om het maatschappelijk leven zo veel mogelijk doorgang te laten hebben en tegelijkertijd sociale contacten zo veel mogelijk te beperken. De maatregelen bevatten allereerst een samenscholingsverbod. Alle bijeenkomsten, samenkomsten en evenementen worden tot maandag 1 juni 2020 verboden (in plaats van tot 6 april); de ondergrens van 100 personen vervalt. Daarnaast wordt het uitoefenen van bijna alle contactberoepen verboden. Verder is anderhalve meter afstand houden nu de regel en kan niet-naleving worden beboet. Vakantieparken, campings, parken, natuurgebieden en stranden mogen door de autoriteiten gesloten worden als er door de bezoekers geen anderhalve meter afstand wordt gehouden. Daarnaast blijven de eerdergenoemde publieke locaties, de horeca en het onderwijs gedurende deze periode gesloten.

\section{Lokale en regionale democratie}

Ook voor het lokaal en regionaal bestuur is deze periode de meest ingrijpende, omdat bestaande democratische vormen gebaseerd zijn op fysiek contact. In deze periode kunnen gemeenteraden geen besluiten nemen en niet samenkomen vanwege bovenstaand verbod. De gemeentelijke politiek ligt dus zo goed als stil. Ook participatieprojecten en bewonersbijeenkomsten die al voor de coronacrisis gepland waren, worden geannuleerd. 


\section{Periode 3: Digitaal bijeenkomen en besluiten ( 9 april tot 1 juli)}

De derde periode wordt gekenmerkt door de eerste versoepelingen voor het sociale verkeer tussen mensen. Voor het lokaal en regionaal bestuur is vooral van belang dat er wetgeving komt die meer mogelijkheden creëert om democratische processen online vorm te geven. De Tijdelijke Wet Digitale Beraadslaging en Besluitvorming maakt de democratische besluitvorming die in de voorgaande periode tot stilstand was gekomen weer mogelijk.

\section{Landelijke maatregelen}

De eerste grote versoepelingen van de coronamaatregelen worden op 6 mei aangekondigd door premier Rutte. Bij deze verruimingen wordt de kans op groepsvorming in de publieke ruimte klein geacht. Tevens komt er een 'routekaart' tot 1 september om de overgang naar de anderhalvemetersamenleving soepeler te laten verlopen. De belangrijkste maatregelen, die vanaf 11 mei ingaan, zijn verder dat basisscholen de deuren vanaf die datum heropenen, dat mensen werkzaam in contactberoepen, onder wie kappers, hun werk weer mogen uitvoeren en dat buiten sporten ook weer wordt toegestaan, met inachtneming van de anderhalve meter afstand. Verdere versoepelingen zijn er vanaf 1 juni. Vanaf die dag gaan restaurants, middelbare scholen, musea, theaters en bioscopen weer open. Over het dragen van mondkapjes is veel discussie. Omdat de anderhalve meter in het openbaar vervoer moeilijk te handhaven is, wordt het dragen van een mondkapje in het openbaar vervoer verplicht.

\section{Lokale en regionale democratie}

Op 8 april 2020 wordt de Tijdelijke Wet Digitale Beraadslaging en Besluitvorming (hierna: Tijdelijke wet) door provincies, gemeenten, waterschappen en openbare lichamen Bonaire, Sint Eustatius en Saba ondertekend. Deze wet treedt een dag later in werking en maakt het sindsdien mogelijk dat decentrale overheden tijdens de coronacrisis op afstand vergaderen en stemmen via digitale middelen. De voorwaarde hierbij is dat de besluitvorming openbaar te volgen moet blijven, bijvoorbeeld via een videoverbinding. Op 25 juni verlengt minister Ollongren van BZK de Tijdelijke wet tot ten minste 1 november.

\section{- Democratische praktijk: vergaderingen van de volksvertegenwoordiging}

Op basis van deze Tijdelijke wet konden vanaf 9 april gemeenteraden, algemene besturen van waterschappen en provinciale staten weer vergaderen en besluiten nemen. Gemeenten gaven op verschillende manieren vorm aan de wet. Zo pakte de gemeenteraad van Groningen de raadsvergaderingen vanaf 13 mei weer op, in hybride vorm. Sommige raadsleden namen fysiek deel aan de vergadering in een aangepaste 'raadszaal', andere raadsleden vergaderden online mee vanuit huis (Gemeente Groningen). Ook in de gemeente Almere werd deze vorm aangehouden bij belangrijke politieke dossiers, zodat belangrijke besluiten nog wel (gedeeltelijk) fysiek konden worden genomen (bron: interview met de gemeente Almere). En waar in de gemeente Leusden in de eerste periode nog met het 'Amersfoortse model' werd gewerkt, werd na de Tijdelijke wet overgegaan op raadsvergaderingen 
via een videoverbinding (www.ad.nl). Inspraak van inwoners werd ook digitaal mogelijk gemaakt. In sommige gemeenten werd gefaciliteerd dat men dit op het gemeentehuis kon doen als men thuis niet beschikt over de juiste middelen (gemeente Teylingen). Niet altijd verliep de digitale inspraakmogelijkheid naar tevredenheid. Zo waren inwoners van Hilversum ontevreden over de mogelijkheden tot inspraak in politieke discussies, omdat de Zoom-stream vastliep, de insprekers slecht verstaanbaar waren en discussies in tijd werden beperkt (www.noordhollandsdagblad.nl).

\section{- Democratische praktijk: inspraak van burgers}

Vanaf eind april werden ook participatieprojecten in toenemende mate weer opgepakt, soms volledig online, maar soms ook in hybride vorm met een combinatie van online en fysieke bijeenkomsten. Zo moesten in de gemeente Amsterdam elf fysieke bewonersbijeenkomsten worden geannuleerd vanwege de coronacrisis. Deze werden vervangen door een online evenement op 19 mei (gemeente Amsterdam). Ook in Den Bosch werden bijeenkomsten via Zoom georganiseerd ter vervanging van geplande fysieke inspraakavonden (gemeente Den Bosch). Regelmatig bleef er bij deze online bijeenkomsten wel een offline mogelijkheid tot participatie voor mensen die minder digitaal onderlegd zijn, zoals via telefonische spreekuren (Amsterdam) of 'dijkgesprekken' in Delfzijl (www.lsabewoners.nl). Op anderhalve meter afstand konden op de dijk in Delfzijl inwoners toch in fysiek overleg treden met de gebiedsregisseur. Een andere creatieve vorm werd gevonden in Groningen, waar bewoners van de wijk Selwerd in een woonwagen in gesprek konden gaan over de vernieuwing van de wijk met de wijkwethouder. In de woonwagen was plek voor drie personen, afgescheiden met plexiglas (www.gic.nl). Veel van de participatieprojecten die in deze periode (online) werden georganiseerd, waren op het gebied van ruimtelijke ordening, zoals herinrichtingen in wijken en nieuwbouwplannen.

\section{Periode 4: Hybride en fysieke bijeenkomsten ( 1 juli tot 30 september)}

In de vierde periode zijn er verdere versoepelingen en komt het maatschappelijk en economisch verkeer weer meer op gang. Ook zien we in het decentraal bestuur een toename in fysieke en hybride vormen van bijeenkomsten.

\section{Landelijke maatregelen}

Vanaf 1 juli zijn alle binnen- en buitensporten en contactberoepen weer toegestaan. Grotere georganiseerde bijeenkomsten zijn ook weer mogelijk. Bij georganiseerde samenkomsten die binnen plaatsvinden, zijn maximaal 100 personen toegestaan.

- Democratische praktijk: vergaderingen van de volksvertegenwoordiging

Doordat vanaf 1 juli fysieke bijeenkomsten toegestaan werden, konden ook gemeenten, provincies en waterschappen weer fysieke bijeenkomsten organiseren. Vergaderingen konden weer plaatsvinden met inachtneming van de corona- 
maatregelen door anderhalve meter afstand te waarborgen, looproutes te maken door de zaal, extra vaak schoon te maken en goed te ventileren. Dit was onder andere te zien in de gemeenten Aalsmeer, De Wolden, Lochem en Purmerend (www.regiopurmerend.nl; gemeente Aalsmeer; gemeente De Wolden; gemeente Lochem). Ook werden vergaderingen vaak gehouden in een fysiek ruimere zaal. Zo week de gemeente Opsterland uit naar het gemeentehuis van buurgemeente Ooststellingerwerf omdat deze wel voldoende ruimte bood en beschikte over de standaardvoorzieningen die nodig zijn voor een livestream (www.sa24.nl). Ook verplichtten sommige gemeenten, waaronder de gemeente Barneveld, het dragen van mondkapjes bij de vergadering (www.scherpenzeelsekrant.nl). Raadsvergaderingen waren in deze periode meestal niet toegankelijk voor publiek, en inspraak van burgers gebeurde overwegend digitaal, maar er waren ook gemeenten die de mogelijkheid creëerden om fysiek in te spreken of aanwezig te zijn (gemeenten Opsterland en Purmerend). Ook konden gemeenten kiezen voor een hybride vorm, zoals gemeente Gooise Meren: besluitvormende vergaderingen vonden digitaal plaats, waarbij raadsleden vanuit huis stemden over verschillende voorstellen. De meningsvormende raadsvergaderingen vonden echter fysiek plaats, waarbij op het gemeentehuis vergaderd werd zonder publiek (gemeente Gooise Meren).

\section{- Democratische praktijk: inspraak van burgers}

$\mathrm{Na}$ het zomerreces werden nog steeds online bewonersbijeenkomsten georganiseerd door gemeenten, maar daarnaast werden ook weer bijeenkomsten georganiseerd waarbij de mogelijkheid werd geboden om fysiek aanwezig te zijn (soms naast de mogelijkheid om online in te bellen). Ook bewonersbijeenkomsten met een uitsluitend fysiek karakter werden weer georganiseerd nu daar, gezien de maatregelen, weer de ruimte voor was. Dan werd bijvoorbeeld gekozen om de bijeenkomst op een grote locatie te houden, op te delen in blokken en de deelnemers te vragen slechts één persoon per huishouden uit te vaardigen (gemeente Sint Anthonis). Ook kozen gemeenten voor inloopbijeenkomsten om inwoners te voorzien van informatie en hen de mogelijkheid te bieden vragen te stellen (gemeente Hattem; www.zuid.zenderstreeknieuws.nl). Daarnaast waren er in deze periode, in vergelijking met de voorgaande, ook meer bijeenkomsten op andere beleidsterreinen dan alleen ruimtelijke ordening. Zo werd ook participatie van inwoners gevraagd op het gebied van sportbeleid, duurzaamheid, mobiliteit en toekomstplannen van de gemeente.

\section{Periode 5: Weer gedeeltelijke lockdown (30 september tot 15 december)}

De vijfde periode die we bespreken, is de periode van de gedeeltelijke lockdown. $\mathrm{Na}$ de zomer is het aantal besmettingen opnieuw toegenomen en zijn we in de tweede coronagolf terechtgekomen. Met name in oktober neet het aantal besmettingen snel toe. 


\section{Landelijke maatregelen}

Als antwoord op de toename van het aantal besmettingen treft het kabinet op 30 september nieuwe maatregelen. Deze zijn in eerste instantie nog beperkt en er vooral op gericht om het aantal sociale contactmomenten tussen mensen te beperken. Het aantal personen per ruimte wordt teruggeschroefd naar 30. Daarnaast adviseert het kabinet dringend om mondkapjes te dragen in publieke binnenruimtes. Twee weken hierna, op 15 oktober, volgt een gedeeltelijke lockdown met als doel de oplopende besmettingen verder te beperken. Het pakket aan maatregelen houdt in dat alle evenementen worden verboden, cafés en restaurants dichtgaan, volwassen (amateur)sport stilgelegd wordt en het maximumaantal van 30 personen per ruimte blijft gelden. Vanaf 1 december wordt het dragen van een mondkapje in publieke ruimtes, winkels, musea en restaurants verplicht voor iedereen ouder dan 12 jaar. Bij het niet dragen van een mondkapje riskeert men een boete van 95 euro. Deze mondkapjesplicht geldt voor in ieder geval drie maanden. Daarnaast zijn sinds 1 december de noodverordeningen vervangen door de Tijdelijke wet maatregelen Covid-19, gezien het voortduren van de coronacrisis.

\section{Lokale en regionale democratie}

$\mathrm{Na}$ het reces wordt op veel plekken de voorkeur gegeven aan fysieke bijeenkomsten, met inachtneming van de coronamaatregelen, zoals zojuist beschreven in de vierde periode. De gedeeltelijke lockdown leidt er echter toe dat al snel weer overgeschakeld wordt op online varianten van vergaderen en besluitvorming. Waar in sommige gemeenten raadsvergaderingen en bewonersbijeenkomsten dus voor korte tijd weer (deels) fysiek plaats kunnen vinden, worden veel van deze fysieke bijeenkomsten toch weer omgezet naar online bijeenkomsten. Dit leidt ertoe dat eind oktober weer met name digitale bijeenkomsten worden georganiseerd door gemeenten. Overigens blijven sommige gemeenten toch de voorkeur houden voor fysiek vergaderen, ondanks de aangescherpte maatregelen, zoals de gemeente Texel, die ook in november nog fysiek in de raadszaal vergadert (gemeente Texel).

\section{Periode 6: Volledige lockdown (15 december tot januari 2021)}

De laatste periode die we bespreken, is de periode van de strengste lockdown tot dusver, die het gevolg is van bijna 10.000 nieuwe besmettingen per dag en de druk op de ziekenhuizen en verpleeghuizen, die hard toeneemt. Op 20 januari is deze lockdown nog verder aangescherpt, aangezien het kabinet grote zorgen heeft om nieuwe virusvarianten.

\section{Landelijke maatregelen}

Om de zorg toegankelijk te houden en het aantal contacten tot een minimum te beperken heeft het kabinet besloten om vanaf 15 december tot en met ten minste 19 januari de strengste lockdown tot dusver af te kondigen. Alle musea, theaters, horecavoorzieningen van hotels en binnensportlocaties worden gesloten. Ook alle 
niet-essentiële winkels en contactberoepen als kappers moeten de deuren sluiten. Daarnaast is al het onderwijs - van basisonderwijs tot universiteiten - op afstand, met uitzondering van praktijkonderwijs en examens. Ook is de kinderopvang gesloten om ouders zo veel mogelijk thuis te laten werken. Thuiswerken blijft een dringend advies voor iedereen, en het openbaar vervoer is enkel voor noodzakelijke reizen bedoeld. Om het aantal contactmomenten nog verder in te dammen is het aantal te ontvangen gasten twee personen, met een uitzondering tijdens de feestdagen van drie gasten. Op 20 januari is de lockdown verder aangescherpt, waarbij het aantal gasten is teruggebracht naar slechts één persoon per dag en het voornemen voor de invoering van een avondklok wordt uitgesproken. Deze avondklok wordt per 23 januari ingevoerd tussen 21.00 en 4.30 uur en tot in ieder geval 9 februari. Deze ingrijpende aanscherping is het gevolg van grote zorgen om de Britse mutatie van het virus, die ook in Nederland gesignaleerd is.

\section{Lokale en regionale democratie}

Voor het lokale en regionale bestuur breekt opnieuw een ingrijpende periode aan. De lockdown heeft als focus het aantal contactmomenten te verlagen, wat maakt dat fysiek bijeenkomen niet wenselijk is. De gemeente Utrecht heeft hierdoor gekozen om alle vergaderingen en bijeenkomsten van de gemeenteraad digitaal te laten plaatsvinden tot er versoepeling van de maatregelen zal plaatsvinden (gemeente Utrecht). Andere gemeenten kiezen voor een aangepaste raadsvergadering door eerst fysiek te vergaderen met slechts één vertegenwoordiger per fractie, en vervolgens met alle raadsleden digitaal een besluitvormende vergadering te hebben (gemeente Groningen). Participatieprojecten en bewonersbijeenkomsten zijn in deze periode fysiek niet mogelijk. Wel kunnen deze bijeenkomsten online doorgang vinden, waarmee in meerdere gemeenten en provincies de afgelopen maanden al geëxperimenteerd is (bron: interview met de provincie Zuid-Holland).

\section{Conclusies: lessen over democratische innovatie}

Het afgelopen jaar was een zeer ingrijpend jaar voor de vormgeving van de democratie op lokaal en regionaal niveau. Praktijken die gelden als 'normaal' werden ineens onmogelijk door de maatregelen die bijeenkomsten verbieden. Het overzicht van deze verschillende perioden laat zien dat in de beginperiode het ontbreken van een juridisch kader de facto leidde tot het stilleggen van de democratie, maar hierop werd snel gereageerd met de Tijdelijke Wet Digitale Beraadslaging en Besluitvorming provincies, gemeenten, waterschappen en openbare lichamen Bonaire, Sint Eustatius en Saba. Na de totstandkoming van deze wet zien we dat lokale en regionale besturen er op allerlei manieren in slagen om de democratie weer op gang te brengen via digitale interacties.

Hoewel er zicht is op een vaccin zal het coronavirus ons nog wel enige tijd in de greep houden en is een terugkeer naar de periode vóór de pandemie op korte termijn nog niet te verwachten. We kunnen onmogelijk weten hoeveel perioden 
er na periode 6 nog zullen komen, maar één ding is zeker: de lokale en regionale democratie blijft overeind door zich aan te passen aan de situatie. Het ontwikkelde juridisch kader maakt het mogelijk om in perioden van zeer beperkt fysiek contact toch de democratie te laten draaien. Hoewel het gaat om een tijdelijke wet, maakt deze periode wel duidelijk dat een juridisch kader nodig is dat het in perioden van crisis mogelijk maakt om de democratie door te laten draaien. En daarbij laten de diverse lokale en regionale praktijken zien dat het vermogen om de democratie te innoveren in tijden van crisis groot is. Innovaties waarover al jaren werd gesproken, konden in de crisis in korte tijd worden doorgevoerd.

In de komende periode staan we voor de vraag om te bekijken wat deze periode van democratische innovatie heeft opgeleverd en welke elementen van deze innovatie we willen behouden. Daarvoor is het zeer belangrijk om goed te kijken naar de betekenis van de nieuwe digitale en hybride democratische praktijken voor de kwaliteit van de democratie aan de hand van criteria als inclusiviteit van deze vormen van interacties, en de kwaliteit en diepgang van de democratische processen. Net zoals corona wellicht de samenleving op een aantal punten blijvend heeft veranderd, heeft deze tijd mogelijk ook een blijvende invloed op de lokale en regionale democratie. Het komende jaar staan we voor de taak om uit deze periode lessen te trekken die blijvend kunnen bijdragen aan het versterken en verrijken van de lokale en regionale democratie.

\section{Noot}

1 Het overzicht van de landelijke coronamaatregelen is opgesteld op basis van de site van de Rijksoverheid (www.rijksoverheid.nl/onderwerpen/coronavirus-covid-19/ nederlandse-maatregelen-tegen-het-coronavirus). De voorbeelden van gemeenten hebben we gehaald uit kwalitatieve interviews, corona-gerelateerd gemeentenieuws en een systematische analyse van geselecteerde Nederlandse gemeenten.

\section{Literatuur}

Gemeentelijke websites

Gemeente Aalsmeer www.aalsmeer.nl/bestuur-organisatie/persbericht/gemeenteraad-vergadert-in-deburgerzaal, geraadpleegd op 22 september 2020.

Gemeente Amsterdam https://deysselbuurt.nl/, geraadpleegd op 25 mei 2020.

Gemeente Den Bosch www.degrootewielenonline.nl/succesvolle-online-bijeenkomst-voor-ontwikkeling-denoordoosthoek/, geraadpleegd op 10 juni 2020.

Gemeente De Wolden www.dewolden.nl/nieuwsoverzicht/artikel/gemeenteraad-gaat-weer-fysiekvergaderen, geraadpleegd op 8 september 2020 .

Gemeente Gooise Meren 
https://gooisemeren.nl/nieuws/item/de-gemeenteraad-in-tijden-van-corona/, geraadpleegd op 22 september 2020.

Gemeente Groningen

https://gemeenteraad.groningen.nl/contact-met-de-raad/Gemeenteraad-en-Corona, geraadpleegd op 25 mei 2020 .

Gemeente Hattem

www.hattem.nl/Onderwerpen/Actueel/Nieuwsberichten/Augustus_2020/

Succesvolle_inloopbijeenkomst_binnenstad, geraadpleegd op 6 november 2020.

Gemeente Lochem

www.lochem.nl/laatste-nieuws/nieuwsbericht/gemeentenieuws/de-gemeenteraad-

vergadert-weer-in-het-gemeentehuis-3611, geraadpleegd op 22 september 2020.

Gemeente Sint Anthonis

www.sintanthonis.nl/inwoners/nieuws_41136/item/5-10-informatiebijeenkomst-thofje-en-toekomstige-woningbouwontwikkeling-ledeacker_46605.html, geraadpleegd op 11 november 2020.

Gemeente Texel www.texel.nl/mozard/!suite05.scherm1070? mNwb=89856\&mNwc=129, geraadpleegd op 11 november 2020.

Gemeente Teylingen

www.teylingen.nl/bestuur-en-organisatie/gemeenteraad/griffie/uw-mening-geven, geraadpleegd op 11 november 2020.

Websites

Ministerie van Binnenlandse Zaken en Koninkrijksrelaties (2020, 19 maart). Continuïteit openbaar bestuur.www.politiekeambtsdragers.nl/publicaties/publicaties/2020/03/19/ continuiteit-openbaar-bestuur, geraadpleegd op 20 mei 2020.

Tijdelijke Wet Digitale Beraadslaging en Besluitvorming provincies, gemeenten, waterschappen en openbare lichamen Bonaire, Sint Eustatius en Saba (2020, 8 april). https://wetten.overheid.nl/BWBR0043375/2020-04-09, geraadpleegd op 15 mei 2020.

www.gic.nl/wonen/woonwagen-voor-bewoners-selwerd-met-vragen-over-wijkvernieuwing, geraadpleegd op 8 juni 2020.

https://sa24.nl/opsterlandse-raad-vergadert-in-oosterwolde/, geraadpleegd op 22 september 2020.

www.scherpenzeelsekrant.nl/lokaal/politiek/368434/eerste-mondkapjes-tijdensbarneveldse-raadsvergadering, geraadpleegd op 27 oktober 2020.

www.ad.nl/amersfoort/burgemeester-leusden-raadsvergadering-zo-snel-mogelijk-via-eenvideoverbinding af8be7c8/, geraadpleegd op 25 mei 2020.

www.noordhollandsdagblad.nl/cnt/dmf20200421_97315420/bewoners-johannesgeradtsweg-hilversum-woedend-over-verloop-commissievergadering-zeer-kwalijk-enonacceptabel?utm_source=google\&utm_medium=organic, geraadpleegd op 10 juni 2020.

https://regiopurmerend.nl/2020/08/25/purmerendse-politiek-gaat-aangepast-weerfysiek-vergaderen/, geraadpleegd op 22 september 2020.

https://zuid.zenderstreeknieuws.nl/nieuws/algemeen/1013260/hoe-gaan-we-duurzameenergie-opwekken-in-ijsselstein-, geraadpleegd op 6 november 2020. 